\title{
Study on the Application and Optimization of Domestic Sewage Treatment Demonstration Based on a Novel Biofilter-Constructed Wetland Coupling System
}

\section{Xiaomin Wang}

Zhejiang Academy of Ecological Environment Design

Yunli Liu

Institute of Hydrobiology Chinese Academy of Sciences

Yi Zhang ( $\sim$ zhangyi@ihb.ac.cn )

Institute of Hydrobiology https://orcid.org/0000-0003-4441-3504

\section{Wenqing Shi}

Nanjing Hydraulic Research Institute

\section{Yifan Yang}

Zhejiang Academy of Ecological and Environment Design

\section{Lingwei Kong}

Westlake University

\section{Research Article}

Keywords: biofilter-constructed wetland, coupling system, big data analysis, domestic sewage treatment, UNEP "Earth Guardian Award"

Posted Date: June 11th, 2021

DOI: https://doi.org/10.21203/rs.3.rs-569836/v1

License: (c) (i) This work is licensed under a Creative Commons Attribution 4.0 International License. Read Full License 


\section{Abstract}

A novel biofilter-constructed wetland coupling system has been applied more than 160 domestic sewage treatment projects in different cities of Zhejiang province, China. The performance of a randomly selected project (flux rate was $27.0 \mathrm{~m}^{3} / \mathrm{d}$ ) based on the coupling system was evaluated in long-term, and the effluent monitoring by big data analysis showed a relatively stable and good water quality. The effluent concentrations of $\mathrm{COD}_{\mathrm{Cr}}, \mathrm{NH}_{4}{ }^{+}-\mathrm{N}$ and TP was $37.57 \pm 11.17 \mathrm{mg} / \mathrm{L}, 5.64 \pm 1.69 \mathrm{mg} / \mathrm{L}$ and $0.82 \pm 0.16$ $\mathrm{mg} / \mathrm{L}$, respectively, which met the first class of "Standards for Discharge of Water Pollutants from Rural Domestic Sewage Treatment Facilities" (DB33/973-2015). The concentrations of effluent TP showed a strong polynomial curve fitting with effluent $\mathrm{NH}_{4}{ }^{+}-\mathrm{N}$ concentrations $\left(\mathrm{R}^{2}=0.9329\right)$ according to the big data analysis. Besides, the concentrations of effluent $\mathrm{COD}_{\mathrm{Cr}}$ had a strong positive linear correlation with the concentrations of effluent $\mathrm{NH}_{4}{ }^{+}-\mathrm{N}\left(\mathrm{R}^{2}=0.9297\right)$, which increased with the increase of effluent TP concentrations $\left(R^{2}=0.6957\right)$. Results also showed $C / N$ had stronger correlation with $\mathrm{pH}\left(\mathrm{R}^{2}=0.6441\right)$, while the concentration of effluent $\mathrm{NH}_{4}{ }^{+}-\mathrm{N}$ and effluent TP had weak correlation with $\mathrm{pH}\left(\mathrm{R}^{2}=0.3348\right.$ and $R^{2}=0.4834$, respectively). The findings might have very important guiding significance for the future monitoring methods of water effluent quality of treatment facility and the cost reduction of monitoring management. Moreover, a demonstration and experiments were carried out for a contrast study of the enhanced system (b) and original system (a). The removal efficiency of $\mathrm{COD}_{\mathrm{Cr}}, \mathrm{NH}_{4}{ }^{+} \mathrm{N}$ and TP of the enhanced system (b) was $81.33 \%, 90.22 \%$, and $75.44 \%$, respectively, which increased by $4.33 \%, 9.11 \%$ and $13.77 \%$ respectively compared to the original system (a).

\section{Introduction}

The pollution of rural domestic sewage has become more and more concerned around the world over the past decade (Zhang et al., 1996; Lutterbeck et al., 2018), especially in developing countries where increasing demand for governance (Sunny et al., 2006; Mohammad et al., 2008). The pollution of rural domestic sewage in China is more complicated due to factors such as its large population base and uneven economic development (Wang et al., 2019; Hong et al., 2019). The large rural population in China results in a huge amount of domestic sewage, and a correspondingly large market. However, the startup of rural domestic sewage treatment is late, and the technologies and process are various, which like anaerobic/aerobic (A/O) (Cui et al., 2016), anaerobic/anoxic/aerobic ( $\left.A^{2} / 0\right)$ (Chen et al., 2011; Liu et al., 2013), integrated purification tank (Cui et al., 2016), Membrane Bio-Reactor (MBR) (Kong et al., 2013a), Multi-stage anaerobic biological filter or Multi-soil-layering system (Chen et al., 2013; Song et al., 2018), constructed wetland (Kong et al., 2013b; Wu et al., 2015; Li et al., 2018), and ecological pond/ditch (Ma et al., 2019). However, these technologies have problems such as unstable processing effect, high energy consumption (Xu et al., 2019), large land occupation, high investment, difficult technical management (Cui et al., 2016), and poor compatibility with ecological landscapes, making the applicability and popularization of these technologies are limited. It is urgent to find a new technology with stable 
processing effect, economically affordable for investment and operating, simple management and coordination with the surrounding landscape (Cameron et al., 2003; Wu et al., 2013; Lu et al., 2019).

Many countries have their own practical in terms of rural domestic sewage treatment technology. Japan mainly uses the "Johkasou" technology which now introduced into China (Kaneko et al., 1997; Ichinari et al., 2008). The predominant treatment technology around the world are high rate algae pond (Godos et al., 2016; Assis et al., 2017), earthworm filter bed or vermifilter (Moon et al., 2010; Liu et al., 2012; Jiang et al., 2016), and constructed wetland (Vymazal, 2007; Vymazal et al., 2014), etc. All of these countries have different pollution concentrations with China and have rather small population density except Japan. Thus, appropriate treatment technology should be selected based on their actual situation in the country.

The rural sewage treatment work in Zhejiang Province is at the forefront of China. Rural green revival program in Zhejiang Province named "Demonstration and Regulation in Thousands of Villages" was granted with the UN award in 2018 after transforming a once heavily polluted area of rivers and streams through the local eco-restoration program. A novel biofilter-constructed wetland coupling system serves as a technical support to help win the "Earth Guardian Award" has been utilized in more than 160 projects in Zhejiang Province. Unlike the conventional structure of constructed wetland system, the novel selfventing biofilter-constructed wetland coupling system adopts a upper and lower stacking structure, and the collecting tank is used as a pretreatment unit to adjust the water volume and to achieve the hydrolysis and acidification in the process, while the substrate is calcium-contained gravel which has the capability of enhanced phosphorus removal (Renman et al., 2010; Vohla et al., 2011). Based on the Bernoulli Principle, a series of enhanced oxygen enrichment technologies for self-ventilation pipe network were developed. In the connected pipe network system, there will be an air flow as long as the air density difference existed at different altitudes and the self-ventilation oxygen enrichment of the biological filter would be accomplished, which could effectively improve the pollutant removal effect. The main causes of air density difference were the temperature difference caused by different environment or the change of air density generated by the consumption of a certain component. Besides, the novel biofilterconstructed wetland coupling system adopt stacking structure, and the collecting and distributing water diversion system was set vertically between the upper and lower layers, alternating the system aerobic, anoxic and anaerobic state to achieve a strong removal of TN. Furthermore, comparing with the conventional constructed wetland, the advantages of this technology are low requirement for the land occupation, low operating cost, non-energy consumption when the sewage in self-flow, and stable with remarkable landscape effect, as well as economic and social benefits.

Although the water effluent of novel biofilter-constructed wetland coupling system could meet the firstclass standard of Zhejiang Provincial "Water Discharge Standard for Rural Domestic Sewage Treatment Facilities" (DB33/973-2015), however, it could not stably reach higher criterion. Therefore, this study aims to evaluate the performance of multiple engineering projects based on the coupling system, and to optimize the coupling system to achieve a better and stable pollutants removal, expanding its application in the field of micro-polluted surface water as well. 


\section{Material And Methods \\ 2.1. Process and material}

Figure 1 is the structure and flow pattern of the biofilter-constructed wetland coupling system. Figure 1 shows that domestic sewage firstly flows through the grille of the regulating tank, then evenly and vertically enters into the biofilter-constructed wetland coupling system through the water distribution system by the lifting of the pump, and filtered by the upper biofilter unit with the enhanced oxygen enrichment of the self-ventilation pipe network system, and then collected at the bottom to vertical water distribution pipes with holes at the lower part, finally flows in a push-flow mode at the bottom of the constructed wetland, further purified under the synergistic action of the constructed wetland filler, microorganisms and plants, and finally discharged. The air connection for the system are tunnel air diffusion devices buried at the bottom of the biofilter bed, connecting the air inlet pipes, also connecting with vertical air extraction pipe extending out of the fillings top surface to attain air convection and automatic oxygen enrichment of the biofilter bed, improving the pollutant removal efficiency and saving the cost of operation and maintenance.

In this study, a project case with the application of this technology $\left(27 \mathrm{~m}^{3} /\right.$ day $)$ was randomly selected and its effluent was monitored and analyzed with continuous big data to evaluate the effluent effect and explore the law of the technology. As shown in Table.1, in order to investigate the engineering effect of this technology, 12 engineering cases ranged from $3 \sim 100 \mathrm{~m}^{3} /$ day were selected and its operation effect was monitored by random sampling.

For further improvement of the sewage treatment effect and operation stability of this technology, a pilotscale comparison ( $50 \mathrm{~m}^{3} /$ day) based on this coupling system was constructed, as shown in Fig. 2 . The two sets of biofilter-constructed wetland coupling comparing systems were separated by a partition wall in the middle. Right side, the biofilter was filled with a mixed filter stone for the original system (a), and on the left filled with different fillers for the enhanced system (b).

As shown in Fig. 2, the effective volume of the grille well in the pilot was $1.50 \mathrm{~m}^{3}$, while the volume of the adjusting tank was $36.00 \mathrm{~m}^{3}$. The area of the biological filter bed was $109.20 \mathrm{~m} 2$ and the height was 1.20 $\mathrm{m}$, with a density of $30 \mathrm{~m}^{2} /$ clumps, placed on the subsurface constructed wetland. The area of the subsurface constructed wetland was $140.2 \mathrm{~m}^{2}$ and the height is $1.50 \mathrm{~m}$. The area of uncovered subsurface constructed wetland was planted with a density of 9 Canna $/ \mathrm{m}^{2}$; The volume of outlet well was $0.25 \mathrm{~m}^{3}$. The parameters for comparative experimental study of novel biofilter constructed wetland coupling system were the same as kong's (Kong et al., 2013a).

\subsection{Influent water indexes of the contrast experiment.}

The water influent was intermittent in both the biological filter bed system and constructed wetland system, controlled by water level of the adjusting tank. The HRT of the two systems were $18.87 \mathrm{~h}$ and $57.54 \mathrm{~h}$, respectively. 


\subsection{Analysis, sampling, and testing methods}

The primary effluent indexes are $\mathrm{COD}_{\mathrm{Cr}}, \mathrm{NH}_{4}{ }^{+} \mathrm{N}$, and TP. The big data is collected by on-line monitoring equipment every two hours.

\section{Results And Discussion}

\subsection{Big data analysis based on a randomly selected engineering project}

More than 160 engineering cases based on the coupling system were applied in different cities of Zhejiang province, and mainly in Kaihua county, which locates in the northwest of Quzhou city. A project using this coupling system was selected and on-line monitoring equipment was added to the effluent section to investigate its long-term effect. The project locates in Xiayu village of Kaihua county, the average influent concentration of $\mathrm{COD}_{\mathrm{Cr}}, \mathrm{NH}_{4}{ }^{+} \mathrm{N}$ and TP of rural domestic sewage in Quzhou city was $113.9 \mathrm{mg} / \mathrm{L}, 27.27 \mathrm{mg} / \mathrm{L}$, and $3.00 \mathrm{mg} / \mathrm{L}$, respectively, which basically represented the average influent water quality of Kaihua county. The main effluent indexes of the project were continuously observed for nearly 160 days, and data were automatically monitored every four hours. From Fig. 3 effluent concentrations of $\mathrm{COD}_{\mathrm{Cr}}, \mathrm{NH}_{4}{ }^{+}-\mathrm{N}$ and TP showed periodic changes, and all of the values were within their standard ranges. Table. 2 showed the effluent values of the main parameters of the project, and the effluent concentrations of $\mathrm{COD}_{\mathrm{Cr}}, \mathrm{NH}_{4}{ }^{+}-\mathrm{N}$, and TP were $37.57 \pm 11.17 \mathrm{mg} / \mathrm{L}, 5.64 \pm 1.69 \mathrm{mg} / \mathrm{L}$, and $0.82 \pm$ $0.16 \mathrm{mg} / \mathrm{L}$, respectively. On the whole, Fig. 3 showed a relatively stable and good effluent water quality, which met the first level of "Standards for Discharge of Water Pollutants from Rural Domestic Sewage Treatment Facilities" (DB33/973-2015).

It also could be found from Table. 2 that the flow rate of the coupling system was $1079.36 \pm 37.79 \mathrm{~m}^{3} / \mathrm{h}$ (ranges from $25.0 \mathrm{~m}^{3} / \mathrm{d}$ to $26.8 \mathrm{~m}^{3} / \mathrm{d}$ ) during the monitoring period, which approaching the designed parameter $\left(27.0 \mathrm{~m}^{3} / \mathrm{d}\right)$. The emergence of the situation that the effluent flow rate was lower than the design flow rate may be related to the gap between the design and the actual situation, leakage or impervious measures in constructed wetland or sewage pipe network, plant transpiration, and other problems.

Figure 4 showed correlations of the main effluent water quality indexes with each other. As shown in Fig. $4(\mathrm{a})$, the concentrations of effluent $\mathrm{COD}_{\mathrm{Cr}}$ had a strong positive linear correlation with the concentrations of effluent $\mathrm{NH}_{4}{ }^{+}-\mathrm{N}\left(\mathrm{R}^{2}=0.9297\right)$, and increased with the increase of effluent TP concentrations in Fig. 4(c) $\left(R^{2}=0.6957\right)$. While in Fig. 4(b), the concentrations of effluent TP showed a strong correlation with effluent $\mathrm{NH}_{4}{ }^{+}-\mathrm{N}$ concentrations $\left(\mathrm{R}^{2}=0.9329\right)$. The results showed that there was a strong correlation between different effluent water quality indexes, and if the sample capacity was large enough, the data would be much more accurate. This founding might have very important guiding significance for the 
future monitoring methods of effluent water quality of treatment facility and the reduction of monitoring management cost, as well as to ensure the main effluent water indexes meet the standard by a combination of big data analysis and Al technology in ways of early warning and feedback control. In this study, the effluent water index of domestic sewage had stronger regularity, and it was found that the effluent also showed a strong correlation when analyzing other treatment objects such as surface water and other process technologies. This might be the result of complex physical, chemical and biological reactions occurred in different facilities, making it more regular than untreated water.

Few relevant studies and reports were found about effluent water index than the influent in literature. Sun (Sun et al., 2014) found that the indicators including $\mathrm{BOD}_{5}, \mathrm{COD}_{\mathrm{Cr}}$, TN and TP had significant simple linear relationships. And the correlation coefficient of $\mathrm{BOD}_{5}$ and $\mathrm{COD}_{\mathrm{Cr}}, \mathrm{BOD}_{5}$ and $\mathrm{TN}, \mathrm{BOD}_{5}$ and $\mathrm{TP}, \mathrm{TN}$, and TP was $0.968,0.995,0.823,0.817$, respectively. Besides, some scholars were looking for new methods that can be used for rapid or low-cost simultaneous monitoring of multiple indicators. Wang (Wang et al., 2019) tried to obtain a satisfactory prediction accuracy modelling approach to identify some hard-to-measure variables like COD and TP by selecting flowrate. Lotfi (Lotfi et al., 2019) presented a methodology to model the quality parameters of effluent wastewater and found that the methodology could accurately predict BOD in wastewater. Narendra (Narendra et al., 2019) developed a feedforward artificial neural network model to predict effluent quality parameters through influent characteristics like $\mathrm{pH}, \mathrm{TSS}, \mathrm{BOD}, \mathrm{COD}, \mathrm{TKN}$, and TP etc.

Figure 5(a)-(d) was the correlations between $\mathrm{pH}$ and effluent $\mathrm{COD}_{\mathrm{Cr}}, \mathrm{NH}_{4}{ }^{+}-\mathrm{N}, \mathrm{TP}, \mathrm{C} / \mathrm{N}$.As shown in Fig. 5, $\mathrm{C} / \mathrm{N}$ showed a stronger correlation with $\mathrm{pH}\left(\mathrm{R}^{2}=0.6441\right)$, while the concentrations of effluent $\mathrm{NH}_{4}{ }^{+}-\mathrm{N}$ and effluent TP had weak correlation with $\mathrm{pH}$, and the correlation coefficient of which was $\mathrm{R} 2=0.3348$ and $\mathrm{R}^{2}$ $=0.4834$, respectively. It could be seen from Fig. 5 (d) that the pH decreased with the increase of $\mathrm{C} / \mathrm{N}$ when the effluent $\mathrm{C} / \mathrm{N}$ was less than 8.5 , thus a method might be derived to fast monitor and control the effluent quality indexes. Moreover, if the amount of data sample was big enough, the effluent $\mathrm{C} / \mathrm{N}$ could be used as a more accurate indicator, and the effluent $\mathrm{C} / \mathrm{N}$ could be indirectly reflected by the change of easily monitored $\mathrm{pH}$ value, making the influent $\mathrm{C} / \mathrm{N}$ could be changed quickly according to the effluent requirements, or the effluent water quality could be improved by fast feedback and the changing of HRT.

Although the project based on the coupling system achieved good and stable effluent water quality, it was only a randomly selected case, and could not represent the entire application effects of the coupling system. Therefore, it was necessary to study more cases and to summarize the actual project effluent effects of this coupling system.

\subsection{Study on the pollutant removal in 12 different randomly selected engineering cases}

As shown in Table.1, in order to better understand the actual engineering effect and existing problems of the technology more comprehensively, 12 engineering cases with different scales (3-100 $\left.\mathrm{m}^{3} / \mathrm{d}\right)$ were randomly selected for the comparative study of pollutant removal effect. 
According to investigation conducted our group in year 2015, the average concentration of $\mathrm{COD}_{\mathrm{Cr}}, \mathrm{NH}_{4}{ }^{+}-\mathrm{N}$ and TP in the influent of Zhejiang Province (except Ningbo) was $186.35 \mathrm{mg} / \mathrm{L}, 30.33 \mathrm{mg} / \mathrm{L}$ and 4.06 $\mathrm{mg} / \mathrm{L}$, respectively, and the average $\mathrm{C} / \mathrm{N}$ of Zhejiang Province was 6.14 , which was beneficial to biological nitrogen and phosphorus removal. The 12 engineering cases in this study mainly located in Quzhou City and Wenzhou city, where contains many mountainous areas. And its average influent concentration of $\mathrm{COD}_{\mathrm{Cr}}, \mathrm{NH}_{4}{ }^{+}-\mathrm{N}$ and TP was $171.73 \mathrm{mg} / \mathrm{L}, 22.14 \mathrm{mg} / \mathrm{L}$ and $3.20 \mathrm{mg} / \mathrm{L}$ respectively, which was lower than the average values of Zhejiang Province. Besides, there were significant differences among these cities $(P<0.05)$. Result showed that the topography and economic development level of mountainous areas had greater impact on the influent water quality.

The data of the study case in Fig. 6 showed that the effluent concentrations of $\mathrm{COD}_{\mathrm{Cr}}, \mathrm{NH}_{4}{ }^{+}-\mathrm{N}$ and TP in the 12 selected projects were $31.23 \mathrm{mg} / \mathrm{L}, 9.27 \mathrm{mg} / \mathrm{L}$ and $0.97 \mathrm{mg} / \mathrm{L}$, respectively, and the removal efficiencys were $81.81 \%, 58.13 \%$ and $69.69 \%$, respectively. Compared with other research results (Lu et al., 2015; Lu et al., 2016), these data were not ideal. However, results of this study reflected the effect of practical engineering application, while other studies were on the bench-scale or pilot-scale. Result of the investigation taken in 2015 found that the average $\mathrm{COD}_{\mathrm{Cr}}, \mathrm{NH}_{4}{ }^{+}-\mathrm{N}$ and TP effluent concentration of Zhejiang Province was $35.62 \mathrm{mg} / \mathrm{L}, 10.90 \mathrm{mg} / \mathrm{L}$ and $1.55 \mathrm{mg} / \mathrm{L}$, respectively. Which means the main effluent indexes of the coupling system were better than that of in Zhejiang Province, and had relatively good treatment effect. Zhejiang rural domestic sewage treatment facilities were required to implemented the Rural Domestic Sewage Treatment Facilities Water Pollutant Discharge Standard (DB33/973-2015) since 2015, in which the effluent $C^{2} D_{C r}$ concentration specified in the first level is $60 \mathrm{mg} / \mathrm{L}$, while the $\mathrm{NH}_{4}{ }^{+}-\mathrm{N}$ concentration is $15 \mathrm{mg} / \mathrm{L}$, and the TP concentration is $2 \mathrm{mg} / \mathrm{L}$. The coupling system could mostly reach the requirement based on the data from previous practical engineering applications but the exceptions of $9 \#$ facility with the effluent $\operatorname{COD}_{\mathrm{Cr}}$ concentration of $69.08 \mathrm{mg} / \mathrm{L}, 4 \#, 6 \#, 8 \#$ and $9 \#$ facility with effluent $\mathrm{NH}_{4}{ }^{+}-\mathrm{N}$ concentration, and $4 \#, 6 \#$ facility with effluent TP concentration all exceeded the first level. It should be noted that for the $6 \#$ facility with continuous monitoring equipment introduced above, its NH4+- $\mathrm{N}$ and TP exceeding standards in this sampling test, which might be related to factors such as the operation phase of the system and the different monitoring time, Therefore, the effluent water quality and stability of practical engineering cases need to be further improved, and the technical process need to be optimized to achieve a stable effluent water quality.

\subsection{Comparative study on the treatment of $\mathrm{COD}_{\mathrm{Cr}}, \mathrm{NH}_{4}{ }^{+}-\mathrm{N}$ and TP in demonstration based on the optimized coupling system.}

As mentioned above, a demonstration comparison system based on this coupling system was conducted (Fig. 2) in order to further improve the sewage treatment effect and operation stability of this technology. Figure 7 showed the long operation and removal of $\mathrm{COD}_{\mathrm{Cr}}, \mathrm{NH}_{4}{ }^{+}-\mathrm{N}$ and TP by the two contrast coupling 
systems. The system-b represents the enhanced system (b) while the system-a stands for the original system (a).

As can be seen from Fig. 7, the variation of $C O D_{C r}$ of influent water was relatively large, which from 350 $\mathrm{mg} / \mathrm{L}$ at the beginning to below $50 \mathrm{mg} / \mathrm{L}$, then suddenly rose to about $400 \mathrm{mg} / \mathrm{L}$ on the 30th day; And gradually declined after the 45th day, lower than $100 \mathrm{mg} / \mathrm{L}$. Compared with the original system (a), the enhanced system (b) had lower effluent $\mathrm{COD}_{\mathrm{Cr}}$ concentration. Especially during the period when the influent $C O D_{C r}$ concentration fluctuates sharply. For example, the effluent $C_{C O}$ concentration of the enhanced system (b) was lower and more stable from the 20th to the 70th day, and the maximum difference of removal efficiency was more than $50 \%$. Figure 7 also showed that the temperature increases with time, and the $\mathrm{COD}_{\mathrm{Cr}}$ removal efficiencys of the two coupled contrast systems were increasing. On the whole, as shown in Table.3, the average $\mathrm{COD}_{\mathrm{Cr}}$ concentration in the influent was $152.81 \pm 130.33 \mathrm{mg} / \mathrm{L}$, while the $\mathrm{COD}_{\mathrm{Cr}}$ concentrations in the effluent of the original system (a) and the enhanced system (b) were $23.63 \pm 13.89 \mathrm{mg} / \mathrm{L}$ and $20.22 \pm 13.37 \mathrm{mg} / \mathrm{L}$, respectively. Vymazal (Vymazal ., 2019) evaluated 17 HFCWs operated for more than 20 years and revealed that the removal efficiency of these systems amounted to $82.9 \%$ for $C O D$, while in this study, the average removal efficiencys of $\mathrm{COD}_{\mathrm{Cr}}$ in the original system (a) and the enhanced system (b) was $77.00 \%$ and $81.33 \%$, respectively. The removal efficiency of $\mathrm{COD}_{\mathrm{Cr}}$ in the enhanced system (b) was higher than that in the original system (a), which rose by $4.33 \%$.

The fluctuation of influent $\mathrm{NH}_{4}{ }^{+}-\mathrm{N}$ was also large during the study period. Figure 7 showed that the concentration range of influent $\mathrm{NH}_{4}{ }^{+} \mathrm{N}$ was $11.10-58.00 \mathrm{mg} / \mathrm{L}$, and the effluent $\mathrm{NH}_{4}{ }^{+} \mathrm{N}$ concentration of the two coupled systems is relatively low and stable in the first 30 days. With the continuous increase of influent $\mathrm{NH}_{4}{ }^{+}-\mathrm{N}$ concentration (up to $58.00 \mathrm{mg} / \mathrm{L}$ ) from 30 to 45 days, the effluent $\mathrm{NH}_{4}{ }^{+}{ }^{-} \mathrm{N}$ concentration of the two coupled systems showed an upward trend, and the effluent $\mathrm{NH}_{4}{ }^{+}-\mathrm{N}$ concentration of the enhanced system (b) was significantly lower than that of the original system (a) $(P<0.05)$. On the 53rd day, the removal efficiency of $\mathrm{NH}_{4}{ }^{+}-\mathrm{N}$ in the original system (a) reached the lowest $27.08 \%$, while that in the enhanced system (b) was close to $80.00 \%$, showing strong stability. In summary, the average $\mathrm{NH}_{4}{ }^{+} \mathrm{N}$ concentration of the original system (a) and the enhanced system (b) was $5.93 \pm 5.29 \mathrm{mg} / \mathrm{L}$ and $2.70 \pm$ $2.49 \mathrm{mg} / \mathrm{L}$, respectively. The average removal efficiency was $81.11 \%$ and $90.22 \%$, respectively. That is to say, the removal efficiency of $\mathrm{NH}_{4}{ }^{+}-\mathrm{N}$ by the enhanced system (b) was $9.11 \%$ higher than that of the original system (a). Yasinta (Yasinta et al., 2020) found the aerated saturated vertical up-flow constructed wetland achieves a high (more than 85\%) removal of $\mathrm{NH}_{4}{ }^{+}-\mathrm{N}$, while the new coupling system had a much higher removal efficiency with nonexternal power assisted aeration process. Different substrates exhibit different adsorption characteristics. Khalifa (Khalifa et al., 2020) found in their research that some traditional used media could boost the pollutants removal capacity of polystyrene foam. Results showed that the removal of $\mathrm{NH}_{4}{ }^{+}-\mathrm{N}$ increased from 66 to $78 \%$, while a better removal effect was obtained in this study without adding polystyrene foam. 
It could be seen from Fig. 7 that the removal effect of TP by the two coupled systems was also very different. Although the influent TP concentration varied considerably, most of the effluent concentrations of the enhanced system (b) were less than $1.00 \mathrm{mg} / \mathrm{L}$. On the whole, the effluent TP concentration of the enhanced system (b) was significantly lower than that of the original system $(a)(P<0.05)$, which maintained a relatively stable TP removal efficiency. The average TP concentration of the original system (a) and the enhanced system (b) was $1.66 \pm 0.73 \mathrm{mg} / \mathrm{L}$ and $1.09 \pm 0.62 \mathrm{mg} / \mathrm{L}$, respectively. The average removal efficiency was $61.67 \%$ and $75.44 \%$ respectively. That is to say, the removal efficiency of TP by the enhanced system (b) was $13.77 \%$ higher than that of the original system (a).

Table. 3 shown the 6 months continuous monitor data of effluent water indexes derived from the officially authorized testing agency. The effluent monitor results of the two comparison systems showed that the effluent $\mathrm{COD}_{\mathrm{Cr}}, \mathrm{NH}_{4}{ }^{+}-\mathrm{N}$ and TP of the demonstration project reached the first level of "Standards for Discharge of Water Pollutants from Rural Domestic Sewage Treatment Facilities" (DB33/973-2015). It could be found from Fig. 7 and Table. 3 that the comparison system showed better removal efficiency compared with the other one, although the influent fluctuated unregularly. And the comparison system had great superiority on the removal of $\mathrm{NH}_{4}{ }^{+} \mathrm{N}$ and TP than that of the original system.

\section{Conclusion}

The performance of engineering case of randomly selected projects and a contrast optimization demonstration based on a novel biofilter-constructed wetland coupling system was investigated.

1) The effluent monitoring of a project (flux rate was $27.0 \mathrm{~m} 3 / \mathrm{d}$ ) by big data analysis showed a relatively stable and good water quality. The effluent concentrations of $\mathrm{COD}_{\mathrm{Cr}}, \mathrm{NH}_{4}{ }^{+} \mathrm{N}$ and TP was $37.57 \pm 11.17$ $\mathrm{mg} / \mathrm{L}, 5.64 \pm 1.69 \mathrm{mg} / \mathrm{L}$ and $0.82 \pm 0.16 \mathrm{mg} / \mathrm{L}$, respectively, which met the first class of "Standards for Discharge of Water Pollutants from Rural Domestic Sewage Treatment Facilities" (DB33/973-2015).

2) The concentrations of effluent TP showed a strong polynomial curve fitting with effluent $\mathrm{NH}_{4}{ }^{+}-\mathrm{N}$ concentrations $\left(R^{2}=0.9329\right)$ according to the large data analysis. The concentrations of effluent $C_{C O}$ had a strong positive linear correlation with the concentrations of effluent $\mathrm{NH}_{4}{ }^{+}-\mathrm{N}\left(\mathrm{R}^{2}=0.9297\right)$, which increased with the increase of effluent TP concentrations $\left(R^{2}=0.6957\right)$. The results may have very important guiding significance for the future monitoring methods of water effluent quality of treatment facility and the cost reduction of monitoring management, as well as early warning and feedback control.

3) The average removal efficiency for $\mathrm{COD}_{\mathrm{Cr}}, \mathrm{NH}_{4}{ }^{+}-\mathrm{N}$ and TP by other 12 projects investigated was $77.52 \%, 58.93 \%$ and $61.01 \%$, respectively; The removal of $\mathrm{COD}_{\mathrm{Cr}}, \mathrm{NH}_{4}{ }^{+} \mathrm{N}$ and TP of the enhanced system of the contrast demonstration was $81.33 \%, 90.22 \%$, and $75.44 \%$, respectively, and which increased by $4.33 \%, 9.11 \%$ and $13.77 \%$ respectively when compared with the original system.

\section{Declarations}


Ethics approval and consent to participate

Not applicable

Consent for publication

Not applicable

Authors' contributions

Xiaomin Wang and Lingwei Kong had the idea for the article, Xiaomin Wang, Yunli Liu and Yi Zhang performed the literature search and data analysis, and Wenqing Shi, Yunli Liu, Yifan Yang, Lingwei Kong and Yi Zhang drafted and/or critically revised the work. All authors read and approved the final manuscript.

Competing interests

The authors declare that they have no competing interests.

Availability of data and materials

All data generated or analysed during this study are included in this published article.

\section{Acknowledgements:}

This work was supported by Zhejiang Provincial Natural Science Foundation of China (No.LY18E080005), National Natural Science Foundation of China (No. 51709254), Support funds project of Zhejiang Provincial key research and development program (No.2019C03110), and Youth Innovation Promotion Association, Chinese Academy of Sciences (No. 2020335). We also thank Mr. Weiwei Shao, Mr. Rongwu Mei, Ms. Can Qian for their great assistance of this experiment.

\section{References}

1. Assis LR, Calijuri ML, Couto EA, Assemany PP (2017) Microalgal biomass production and nutrients removal from domestic sewage in a hybrid high-rate pond with biofilm reactor. Ecol Eng 106:191199

2. Cameron K, Madramootoo C, Crolla A, Kinsley C (2003) Pollutant removal from municipal sewage lagoon effluents with a free-surface wetland. Water Res 37:2803-2812

3. Chen Y, Peng C, Wang J, Ye L, Zhang L, Peng Y (2011) Effect of nitrate recycling ratio on simultaneous biological nutrient removal in a novel anaerobic/anoxic/oxic (A2/0)-biological aerated filter (BAF) system. Bioresource Technol 102:5722-5727

4. Chen $\mathrm{H}$, Zhang MM (2013) Occurrence and removal of antibiotic resistance genes in municipal wastewater and rural domestic sewage treatment systems in eastern China. Environ Int 55:9-14 
5. Cui X, Kong LW, Wei YF, Xu MH, Hu ZF, Ye HY, Huang GZ, Wang FC (2016) Study on the making of draft version technical specifications of Zhejiang Province rural sewage emission reduction verification. Environment Sustainable Development 3:159-164. (in Chinese)

6. Godos I, Arbib Z, Lara E, Rogalla F (2016) Evaluation of High Rate Algae Ponds for treatment of anaerobically digested wastewater: Effect of $\mathrm{CO} 2$ addition and modification of dilution rate. Bioresource Technol 220:253-261

7. Hong YY, Huang GH, An CJ, Song P, Xin XY, Chen XJ, Zhang P, Zhao YY, Zheng RB (2019) Enhanced nitrogen removal in the treatment of rural domestic sewage using verticalflow multi-soil-layering systems: Experimental and modeling insights. J Environ Manage 240:273-284

8. Ichinari T, Ohtsubo A, Ozawa T, Hasegawa K, Teduka K, Oguchi T, Kiso Y (2008) Wastewater treatment performance and sludge reduction properties of a household wastewater treatment system combined with an aerobic sludge digestion unit. Process Biochem 43:722-728

9. Jiang LH, Liu YG, Hu XJ, Zeng GM, Wang H, Zhou L, Tan XF, Huang BY, Liu SB, Liu SM (2016) The use of microbial-earthworm ecofilters for wastewater treatment with special attention to influencing factors in performance: A review. Bioresource Technol 200:999-1007

10. Kaneko M (1997) Virus removal by the domestic waste water treatment system named johkasou. Water Sci Technol 35:187-191

11. Khalifa ME, El-Reash YGA, Ahmed MI, Rizk FW (2020) Effect of media variation on the removal efficiency of pollutants from domestic wastewater in constructed wetland systems. Ecol Eng 143:105668

12. Kong LW, He F, Xia SB, Xu D, Zhang Y, Wu ZB (2013a) Study on the DMBR-IVCW combined process for the treatment of domestic wastewater. Technol Water Treatment 39:57-62. (in Chinese)

13. Kong LW, He F, Xia SB, Xu D, Zhang Y, Xiao ER, Wu ZB (2013b) A combination process of DMBR-IVCW for domestic sewage treatment. Fresen Environ Bull 22:665-674

14. Li HF, Liu F, Luo P, Xie GX, Xiao RL, Hu W, Peng JW, Wu JS (2018) Performance of integrated ecological treatment system for decentralized rural wastewater and significance of plant harvest management. Ecol Eng 124:69-74

15. Liu J, Lu ZB, Yang J, Xing MY, Yu F, Guo MT (2012) Effect of earthworms on the performance and microbial communities of excess sludge treatment process in vermifilter. Bioresource Technol $117: 214-221$

16. Liu G, Xu X, Zhu L, Xing S, Chen J (2013) Biological nutrient removal in a continuous anaerobicaerobic-anoxic process treating synthetic domestic wastewater. Chem Eng J 225:223-229

17. Lotfi K, Bonakdari H, Ebtehaj I, Mjalli FS, Zeynoddin M, Delatolla R, Gharabaghi B (2019) Predicting wastewater treatment plant quality parameters using a novel hybrid linear nonlinear methodology. $\mathrm{J}$ Environ Manage 240:463-474

18. Lu SB, Pei L, Bai X (2015) Study on method of domestic wastewater treatment through new-type multi-layer artificial wetland. Int J Hydrogen Energ 40:11207-11214 
19. Lu SB, Zhang XL, Wang JH, Pei L (2016) Impacts of different media on constructed wetlands for rural household sewage treatment. J Clean Prod 127:325-330

20. Lu SB, Gao XR, Wu P, Li W, Bai X, Sun M, Wang A (2019) Assessment of the treatment of domestic sewage by a vertical-flow artificial wetland at different operating water levels. J Clean Prod 208:649655

21. Lutterbeck CA, Zerwes FV, Radtke JF, Köhler A, Kist LT, Machado ÊL (2018) Integrated system with constructed wetlands for the treatment of domestic wastewaters generated at a rural propertyEvaluation of general parameters ecotoxicity and cytogenetics. Ecol Eng 115:1-8

22. Ma L, Liu W, Tan QY, Zhou QH, Wu ZB, He F (2019) Quantitative response of nitrogen dynamic processes to functional gene abundances in a pondditch circulation system for rural wastewater treatment. Ecol Eng 134:101-111

23. Mohammad AS, Nidal M (2008) Start-up of an UASB-septic tank for community on-site treatment of strong domestic sewage. Bioresource Technol 99:7758-7766

24. Moon KE, Lee SY, Lee SH, Ryu HW, Cho KS (2010) Earthworm cast as a promising filter bed material and its methanotrophic contribution to methane removal. J Hazard Mater 176:131-138

25. Narendra K, Kamal K, Abhishek S (2019) Prediction of effluent quality in ICEAS-sequential batch reactor using feedforward artificial neural network. Water Sci Technol 80. 10.2166/wst.2019.257

26. Renman A, Renman G (2010) Long-term phosphate removal by the calcium silicate material Polonite in wastewater filtration systems. Chemosphere 79:659-664

27. Song P, Huang GH, An CJ, Shen J, Zhang P, Chen XJ, Shen J, Yao Y, Zheng RB, Sun CX (2018) Treatment of rural domestic wastewater using multi-soil-layering systems: Performance evaluation, factorial analysis and numerical modeling. Sci Total Environ 644:536-546

28. Sun Y, Zhang F, Hu HY, Niu ZB (2014) Statistical analysis of influent quality characteristics of municipal wastewater treatment plants in Shanghai, China. Chinese Journal of Environmental Engineering 8:5167-5173

29. Sunny A, Ilse F, De KL, Adrianus vanH, Willy V (2006) Anaerobic and complementary treatment of domestic sewage in regions with hot climates-A review. Bioresource Technol 97:2225-2241

30. Vohla C, Kõiv M, Bavor HJ, Chazarenc F, Mander Ü (2011) Filter materials for phosphorus removal from wastewater in treatment wetlands-a review. Ecol Eng 37:70-89

31. Vymazal J (2007) Removal of nutrients in various types of constructed wetlands. Sci Total Environ 380:48-65

32. Vymazal J, Březinová T (2014) Long term treatment performance of constructed wetlands for wastewater treatment in mountain areas: Four case studies from the Czech Republic. Ecol Eng 71:578-583

33. Vymazal J (2019) Is removal of organics and suspended solids in horizontal sub-surface flow constructed wetlands sustainable for twenty and more years? Chem Eng J 378:122117 
34. Wang XD, Kvaal K, Ratnaweera H (2019) Explicit and interpretable nonlinear soft sensor models for influent surveillance at a fullscale wastewater treatment plant. J Process Contr 77:1-6

35. Wu H, Zhang J, Ngo HH, Guo W, Hu Z, Liang S, Fan J, Liu H (2015) A review on the sustainability of constructed wetlands for wastewater treatment: design and operation. Bioresource Technol 175:594-601

36. Wu YF, Zhu WB, Lu XW (2013) Identifying key parameters in a novel multistep bio-ecological wastewater treatment process for rural areas. Ecol Eng 61:166-173

37. Xu MJ, Zhu SK, Zhang Y, Wang HL, Fan B (2019) Spatial-temporal economic analysis of modern sustainable sanitation in rural China: Resource-oriented system. J Clean Prod 233:340-347

38. Yasinta J, Guenter L, Victor MAT, E.D (2020) Aeration intensity simulation in a saturated vertical upflow constructed wetland. Sci Total Environ 708:134793

39. Zhang ZN, Su G, Ge GL, Zhao GY, Wu ZY (1996) Rural sanitary domestic flushing toilet system. Water Res 30:2826-2829

\section{Tables}

Table.1 Information summary of randomly selected engineering case

\begin{tabular}{|lllll|}
\hline Item & Project name & $\begin{array}{l}\text { Operation From } \\
(\text { year })\end{array}$ & $\begin{array}{l}\text { Treatment Scale } \\
\left(\mathrm{m}^{3} / \mathrm{d}\right)\end{array}$ & $\begin{array}{l}\text { HRT } \\
(\mathrm{d})\end{array}$ \\
\hline $1 \#$ & Shifan & 2015 & 33 & 3 \\
\hline $2 \#$ & Yangkengkou-1 & 2014 & 16 & 3 \\
\hline $3 \#$ & Yangkengkou-2 & 2014 & 25 & 3 \\
\hline $4 \#$ & Xiajia & 2014 & 36 & 3 \\
\hline $5 \#$ & Yaojia & 2014 & 36 & 3 \\
\hline $6 \#$ & Xiayu & 2014 & 27 & 3 \\
\hline $7 \#$ & Zhongfanshangyou & 2015 & 11 & 3 \\
\hline $8 \#$ & Chenjia & 2014 & 21 & 3 \\
\hline $9 \#$ & Yangjiashan & 2014 & 3 & 3 \\
\hline $10 \#$ & Jincun & 2011 & 50 & 3 \\
\hline $11 \#$ & Nanyangcun & 2014 & 100 & 3 \\
\hline $12 \#$ & Wanlicun & 2014 & 40 & \\
\hline
\end{tabular}

Table.2 The effluent values of the main parameters of the project 


\begin{tabular}{|lll|}
\hline Item & Variety Range & Average Value \\
\hline $\mathrm{pH}$ & $6.45 \sim 6.57$ & $6.51 \pm 0.04$ \\
\hline $\mathrm{COD}_{\mathrm{Cr}}(\mathrm{mg} / \mathrm{L})$ & $12.70 \sim 54.11$ & $37.57 \pm 11.17$ \\
\hline $\mathrm{NH}_{4}{ }^{-} \mathrm{N}(\mathrm{mg} / \mathrm{L})$ & $2.09 \sim 8.99$ & $5.64 \pm 1.69$ \\
\hline $\mathrm{TP}(\mathrm{mg} / \mathrm{L})$ & $0.63 \sim 1.10$ & $0.82 \pm 0.16$ \\
\hline $\mathrm{C} / \mathrm{N}$ & $5.65 \sim 11.34$ & $6.67 \pm 0.64$ \\
\hline Flow rate $(\mathrm{m} 3 / \mathrm{h})$ & $1022.61 \sim 1166.58$ & $1079.36 \pm 37.79$ \\
\hline
\end{tabular}

Table.3 The water quality of two contrast systems

\begin{tabular}{|llll|}
\hline Item & Inf.of water & Eff.of original-(a) & Eff.of enhanced-(b) \\
\cline { 2 - 4 } & $\mathrm{mg} / \mathrm{L}$ & $\mathrm{mg} / \mathrm{L}$ & $\mathrm{mg} / \mathrm{L}$ \\
\hline CODCr & $152.81 \pm 130.33$ & $23.63 \pm 13.89$ & $20.22 \pm 13.37$ \\
\hline $\mathrm{NH} 4+-\mathrm{N}$ & $36.76 \pm 13.46$ & $5.93 \pm 5.29$ & $2.70 \pm 2.49$ \\
TP & $4.63 \pm 1.37$ & $1.66 \pm 0.73$ & $1.09 \pm 0.62$ \\
\hline
\end{tabular}

\section{Figures}

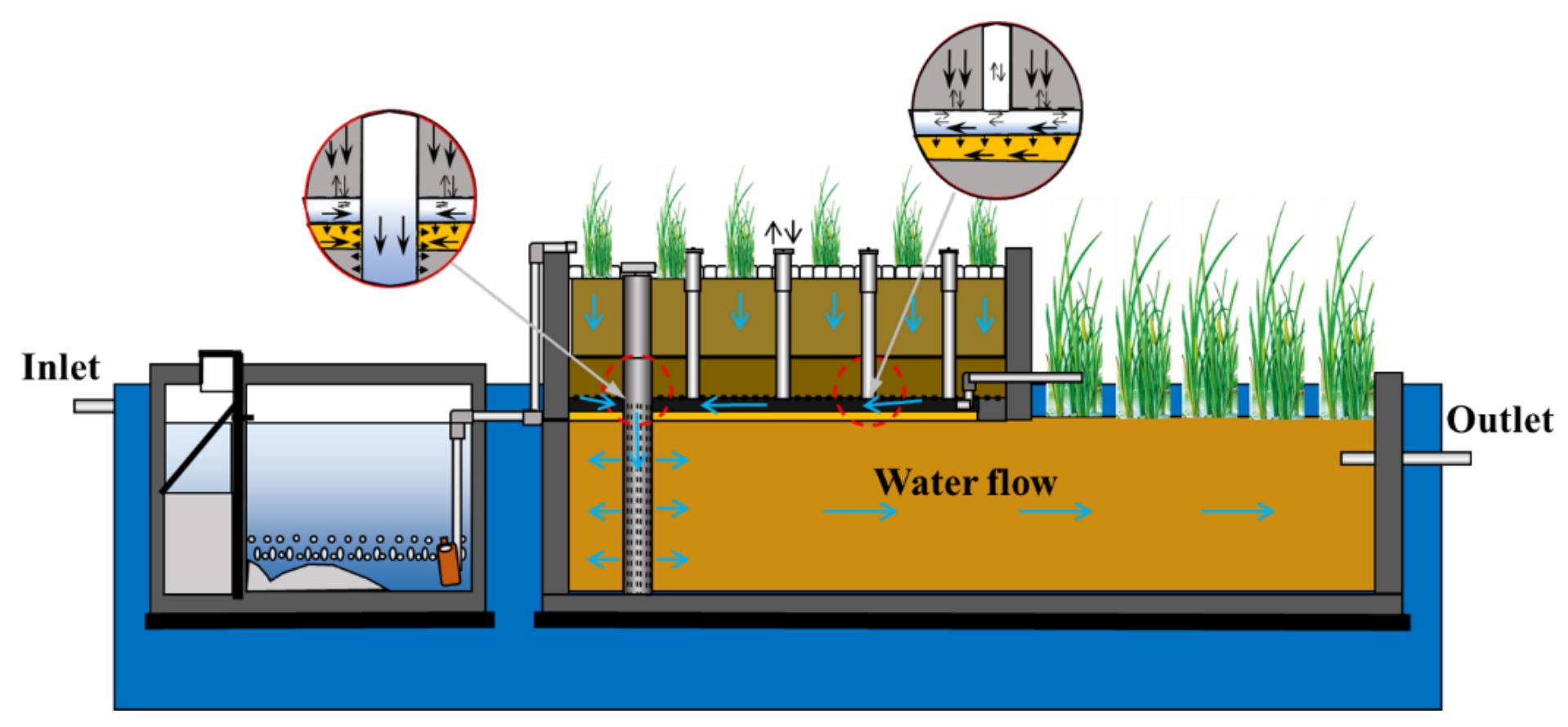

Figure 1 
The schematic and water flow of the novel biofilter-constructed wetland coupling system

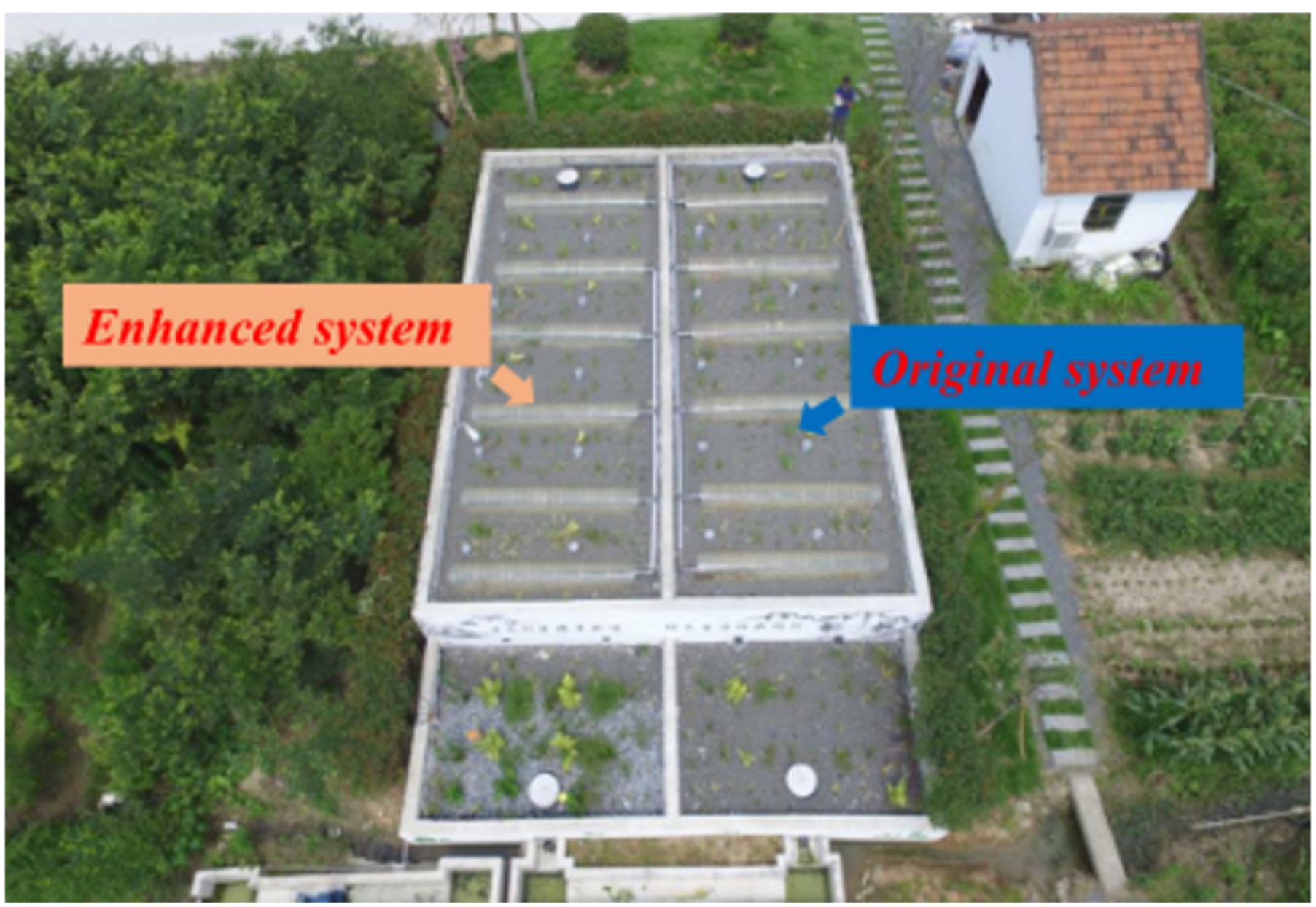

Figure 2

The comparative demonstration based on the coupling system 


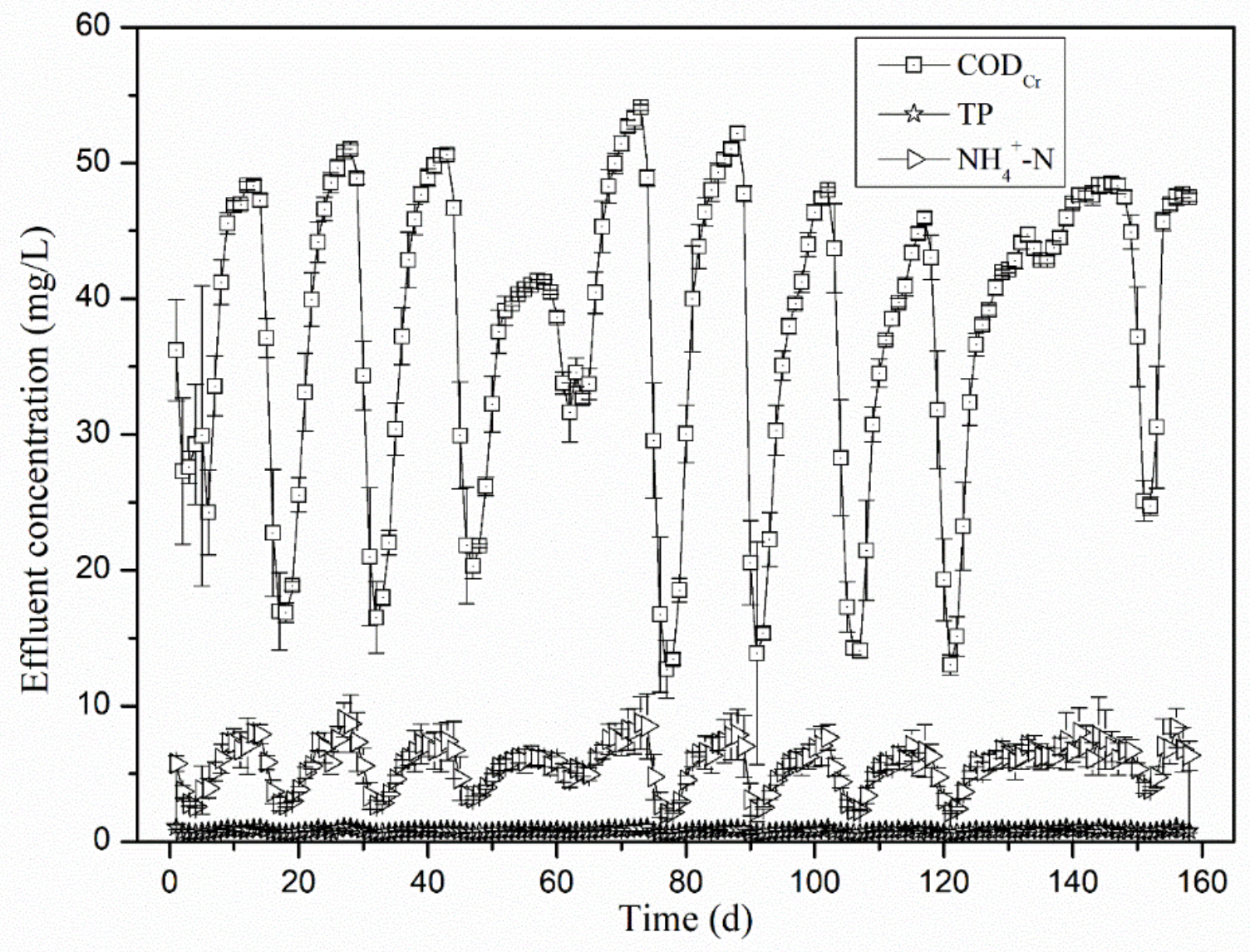

Figure 3

Variation of the effluent of former project based on the novel coupling system 

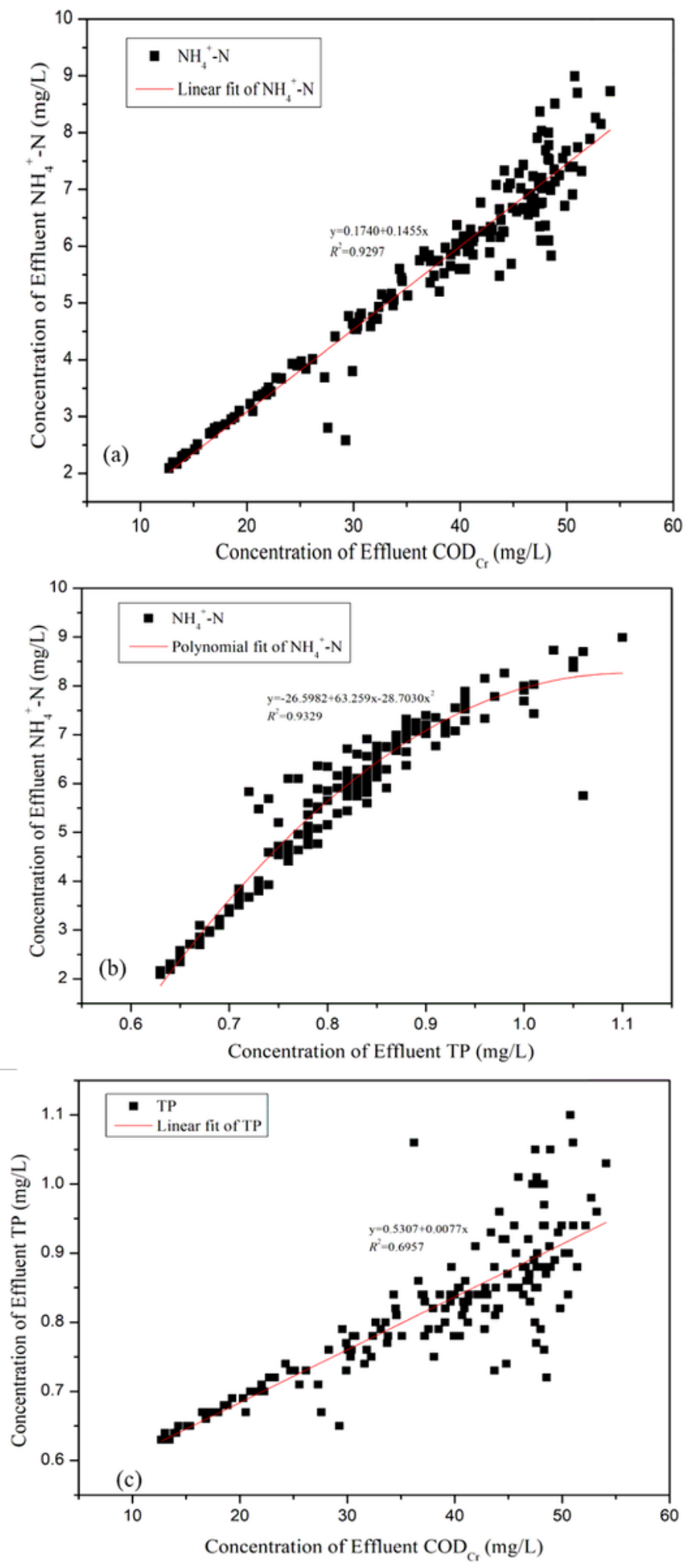

Figure 4

Correlations between the main effluent water quality indexes

Page $17 / 20$ 

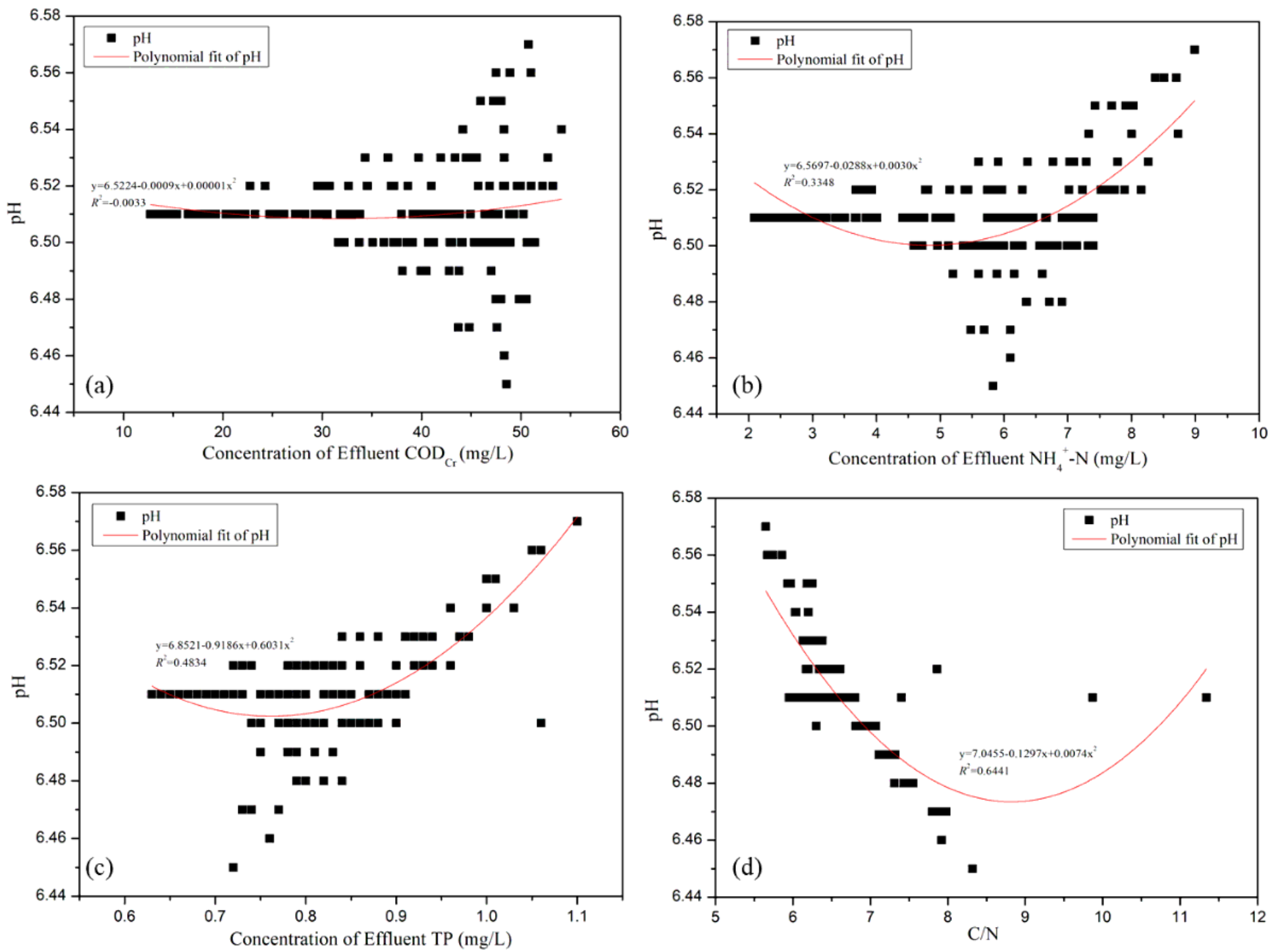

Figure 5

Correlations between $\mathrm{pH}$ and effluent $\mathrm{CODCr}, \mathrm{NH} 4+-\mathrm{N}, \mathrm{TP}, \mathrm{C} / \mathrm{N}$ 

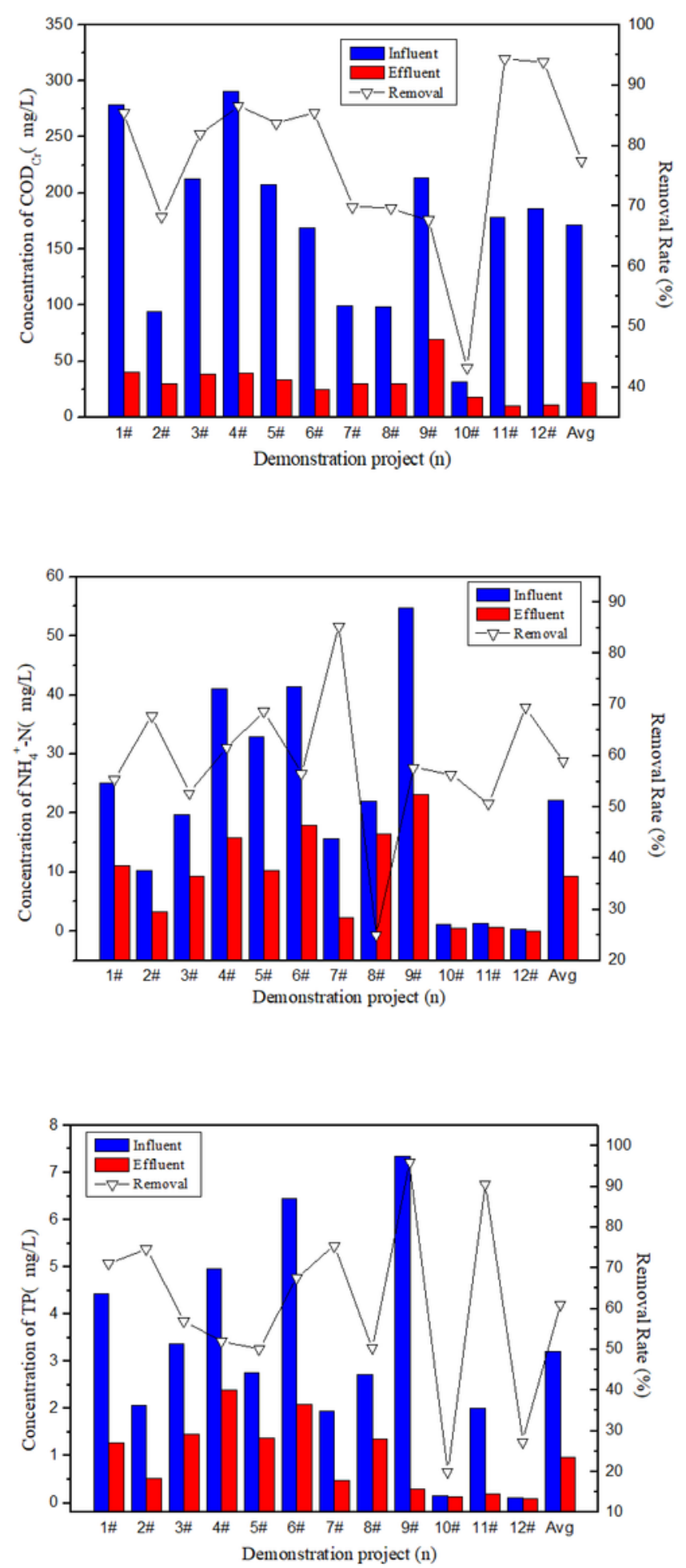

Figure 6

Treatment performance of the novel biofilter-constructed wetland system 

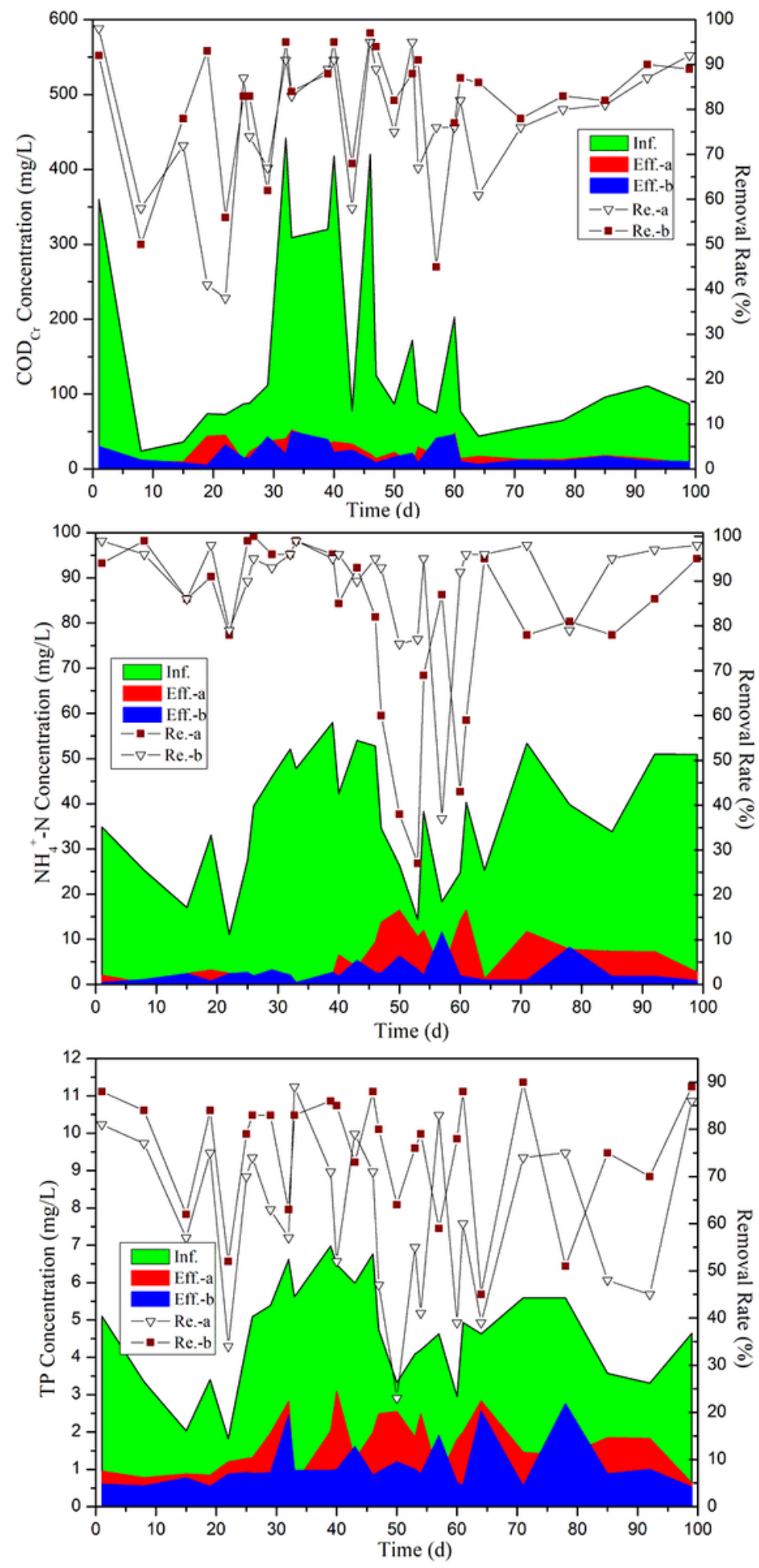

Figure 7

Removal of CODCr, NH4+-N and TP by the two contrast coupling systems (The system-b represents the enhanced system, while the system-a stands for the original system) 